\title{
PROFESOR DR HAB. LESZEK KAJZER (1944-2016)
}

Dnia 25 września 2016 r. zmarł Profesor Leszek Kajzer, powszechnie szanowany i cieszący się wielkim autorytetem Uczony: archeolog, historyk oraz historyk kultury materialnej, sztuki i architektury.

Urodził się 11 sierpnia 1944 r. w Milanówku. Od 1950 r. przeniósł się do Łodzi, z którą był związany do ostatnich dni. Także w Uniwersytecie Łódzkim zaczął studia na Wydziale Filozoficzno-Historycznym na kierunku archeologia. Już w trakcie studiów wyróżniał się pasją badawczą. Swoją karierę badacza rozpoczął od badania jaskiń, później zajmował się okresem rzymskim (tego czasu dotyczą pierwsze publikacje). Jednak już na ostatnim roku studiów zdecydowanie zaczęło przeważać zainteresowanie problematyką budownictwa obronnego, którą, z krótką przerwą na badania bronioznawcze, zajmował się przez całe życie.

Studia ukończył w 1967 r., przygotowując pracę magisterską Wspótczesny stan badań nad zagadnieniami ciagłości osadnictwa pod kierunkiem prof. dr. hab. Konrada Jażdżewskiego. Jeszcze w tym samym roku został zaangażowany w Zakładzie Archeologii Polski Środkowej Instytutu Historii Kultury Materialnej PAN, w Pracowni Historii Dawnego Uzbrojenia, której kierownikiem był prof. dr Andrzej Nadolski. Tam wraz z Z. Wawrzonowską i M. Głoskiem zajmował się problemami średniowiecznego uzbrojenia. Jednym $\mathrm{z}$ rezultatów wspomnianych badań była praca Uzbrojenie $i$ ubiór rycerski $w$ średniowiecznej Matopolsce $w$ świetle źródet ikonograficznych, która stała się podstawą doktoratu, obronionego w 1973 roku.

W 1978 r. Leszek Kajzer przeniósł się do Katedry Archeologii Uniwersytetu Łódzkiego, gdzie piął się po kolejnych szczeblach kariery naukowej. W 1980 r. uzyskał stopień doktora habilitowanego na podstawie wysoko ocenionej rozprawy Studia nad świeckim budownictwem obronnym województwa tęczyckiego w XIII-XVII wieku. Następnie od 1990 r. został zatrudniony na etacie profesora, najpierw nadzwyczajnego, tzw. „rektorskiego”, a później, po otrzymaniu tytułu profesorskie-

\footnotetext{
* Instytut Archeologii UŁ, ul. Narutowicza 65, 90-131 Łódź.
} 


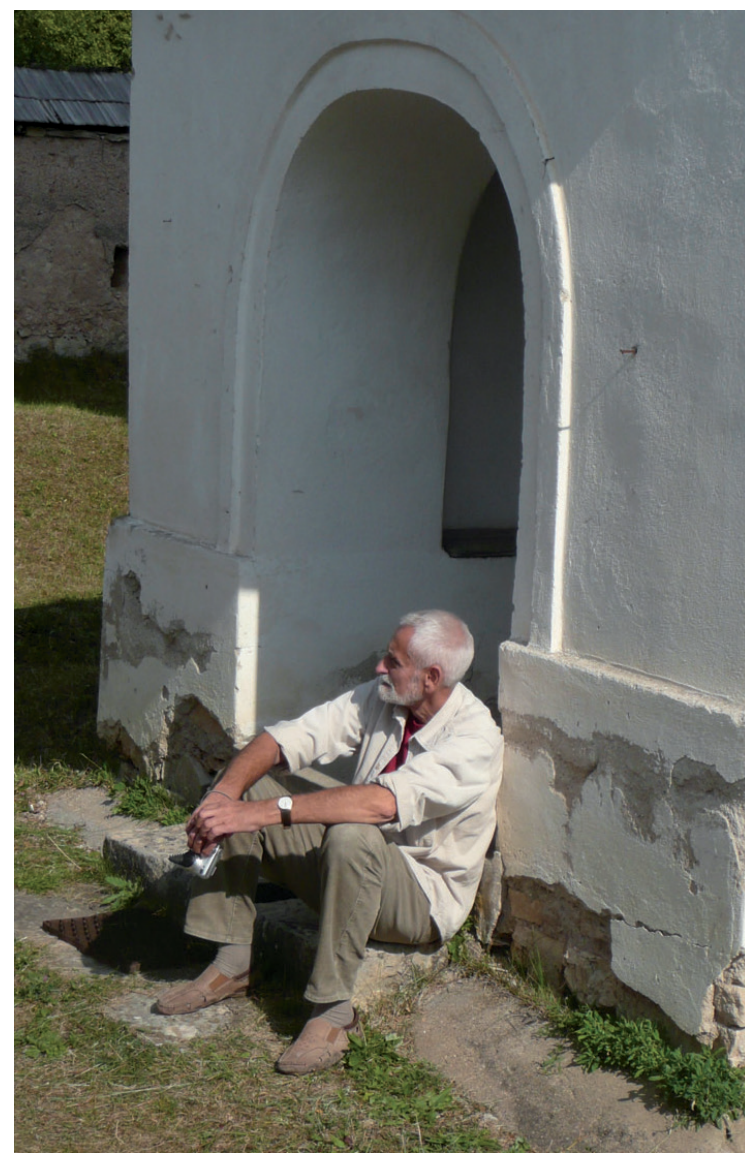

go, od 1991 r. tzw. ,ministerialnego". Od 1995 r. do śmierci był zatrudniony na etacie profesora zwyczajnego.

Po zatrudnieniu na uczelni jedną z Jego pasji stała się dydaktyka. Mogę tutaj stwierdzić, jako jeden z Jego pierwszych słuchaczy, że zajęcia te wniosły nową jakość w naszą studencką codzienność. Były to zajęcia, co dzisiaj jest normą, ,interaktywne", zmuszające uczestników nie tylko do bezkrytycznego prezentowania nabytej samodzielnie wiedzy, ale do myślenia, formułowania swoich opinii i właściwego kojarzenia faktów. Wielowątkowość zainteresowań naukowych powodowała, że był nauczycielem o wielkim autorytecie. Bardzo lubiany przez studentów, pomimo stanowczości i surowości, za sprawiedliwość w ocenach, życzliwość i umiejętność rozwiązywania problemów najprostszymi metodami.

Dorobek dydaktyczny Profesora Kajzera był doceniany i wysoko oceniany także przez archeologów, zarówno w Łodzi, jak i w Polsce i Europie. Pod Jego opieką zdobyło dyplomy licencjackie ponad 30 osób, magisterskie zaś 190 osób.

Nie można także zapominać, że był jednym z twórców archeologii historycznej i Profesorem, który wprowadził ją do nauczania archeologii, która w programie nauczania jeszcze w latach 70. XX w. kończyła się na wczesnym średniowieczu. Po utworzeniu Instytutu Archeologii Uniwersytetu Łódzkiego w jego ramach powstała pierwsza w Polsce Katedra Archeologii Historycznej, którą kierował Profesor Kajzer.

Od roku akademickiego 1985/1986 Profesor Kajzer prowadził seminaria doktorskie. W ciągu tego czasu odbyło się ich ponad 300. Tematyka tych spotkań, skupiających nie tylko doktorantów Profesora, była bardzo różnorodna. Prezentowano przede wszystkim zagadnienia związane ze studiami mającymi zakończyć się rozprawami doktorskimi. Swoje badania przedstawiali także doktoranci prowadzeni przez innych promotorów, również z dziedzin innych niż archeologia. Sporo czasu poświęcano także szeroko rozumianej ochronie zabytków, stanowisk arche- 
ologicznych i szeroko rozumianego dziedzictwa narodowego. Dużą część czasu zawsze zajmowała żywa dyskusja, natomiast podsumowania Profesora ujęte przeważnie lapidarnie, w kilku celnych uwagach były niezwykle cenne dla prezentujących wyniki swoich prac. Efektem tej działalności było 16 ukończonych doktoratów. Czasami prelegentami byli także doświadczeni i utytułowani badacze dzielący się swymi najnowszymi, czasami kontrowersyjnymi opracowaniami.

Trzeba także dodać, że Profesor, poza tymi oficjalnymi spotkaniami, zawsze znajdował czas, aby wspólnie przeanalizować zebrane materiały. Zawsze można było liczyć na Jego żywe zainteresowanie i pomoc w potrzebie. Za przykład może tutaj służyć moje wspomnienie, kiedy jako młody archeolog zaczynający swoje samodzielne badania spędzałem razem z Profesorem wiele godzin nad planami rozłożonymi na czerwonej wykładzinie dywanowej w Jego gabinecie.

Omawiając działalność dydaktyczną Profesora Leszka Kajzera, nie można także zapomnieć o Jego aktywności administracyjnej, niezbędnej dla procesu dydaktycznego. W latach 1992-1996 był kierownikiem Katedry Ar-

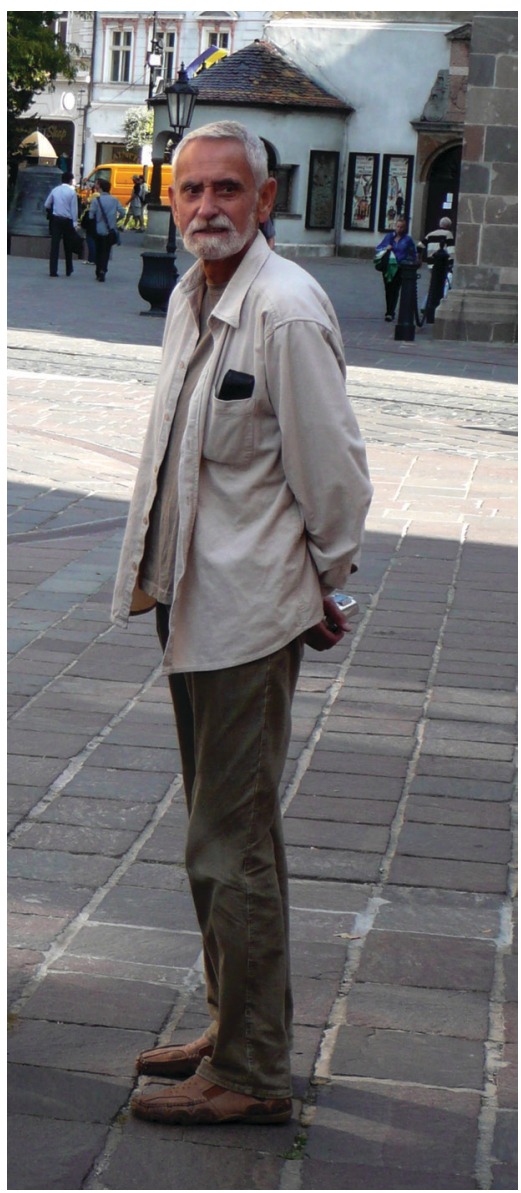
cheologii Uniwersytetu Łódzkiego, od roku 1996 do 2008 zaś dyrektorem Instytutu Archeologii Uniwersytetu Łódzkiego, do powołania którego niezłomnie dążył.

Profesor Leszek Kajzer był także wybitnym badaczem. Rolę dominującą w Jego dorobku zajmowały badania archeologiczne-architektoniczne. Prowadził liczne i długotrwałe badania terenowe obiektów architektury murowanej, zarówno o charakterze obronnym, a więc zamków, dworów obronnych, wiejskich siedzib obronnych i wszelkich innych obiektów mieszczących się w określeniu ,budownictwo obronne", jak i rezydencjonalnym, gdzie w polu zainteresowań były dwory i pałace. Kolejny obszar badawczy stanowiły obiekty sakralne, a więc zespoły klasztorne, klasztorno-pałacowe czy poszczególne świątynie. Badania na ponad 100 stanowiskach objęły swoim zakresem terytorium całej Polski, choć koncentrowały się głównie na historycznych Ziemiach Łęczyckiej i Sieradzkiej, Sandomierszczyźnie, Kujawach i ziemi dobrzyńskiej, Pomorzu Gdańskim, Górnym Śląsku i w Małopolsce. Profesor Kajzer badał także stanowiska w wielu krajach europejskich: Wielkiej Brytanii, Danii, Hiszpanii, na Węgrzech, w Czechosłowacji. 
Zawsze w badaniach terenowych uczestniczyło liczne grono współpracowników i studentów, a także licznych gości reprezentujących inne dyscypliny naukowe, co powodowało możliwość długich dyskusji, otwierających, jeszcze w terenie, możliwości nowych czy innych interpretacji dokonanych odkryć.

Jedną z najważniejszych cech, wyróżniających Profesora Kajzera spośród innych badaczy jest jego imponująca twórczość naukowa. Jego dorobek obejmuje blisko 600 pozycji, w tym 26 książek. Jego prace publikowane były w 15 krajach Europy i Stanach Zjednoczonych. Wśród najważniejszych należy wymienić monumentalne dzieło wymyślone i zredagowane przez Leszka Kajzera Leksykon zamków polskich (Warszawa 2001), będące kompendium wiedzy castellologicznej początku XXI wieku. Kolejne dwa to sensu stricte podręczniki akademickie do dziś aktualne i jedyne, napisane na potrzeby rozwijającej się archeologii historycznej: Wstęp do badań archeologiczno-architektonicznych (Łódź 1984) i Wstęp do archeologii historycznej w Polsce (Łódź 1996). Równie istotna jest praca Zamki i społeczeństwo (Łódź 1993), będąca podręcznikiem historii budownictwa obronnego Polski od początku państwa do schyłku Rzeczpospolitej szlacheckiej napisanym z perspektywy archeologa. Z innych pozycji wymienić należy opublikowaną w $2010 \mathrm{r}$. książkę Dwory w Polsce. Od średniowiecza do nowożytności. Jest ona pierwszą próbą sumarycznego ujęcia tej problematyki w polskiej literaturze. Nie można także zapominać o istocie warsztatu badacza, jakim jest szybkie publikowanie wyników badań, a w tej materii Profesor był niedościgłym mistrzem.

W 2008 r. Profesor Kajzer zrezygnował z kierowania Instytutem Archeologii UŁ. Natomiast dydaktykę i pracę naukową realizował do ostatnich dni. Bogactwo wiedzy, zainteresowań oraz zaangażowanie w pracę różnych organizacji instytutów naukowych zaowocowało członkostwem najbardziej prestiżowych towarzystw naukowych polskich i zagranicznych. Z bardzo długiej listy wymienić wypada przewodniczenie Radzie Naukowej Instytutu Archeologii i Etnologii PAN oraz członkostwo: Polskiego Komitetu Narodowego ICOMOS; międzynarodowych korporacji badaczy zamków Castrum Bene i Castella Maris Baltici, Rady Programowej Narodowego Instytutu Dziedzictwa; Komitetu Nauk Pre- i Protohistorycznych; Rady Ochrony Zabytków przy kolejnych Ministrach Kultury i Dziedzictwa Narodowego, rad naukowych wielu muzeów oraz wielu towarzystw naukowych.

W pamięci przyjaciół, koleżeństwa i wychowanków pozostanie na zawsze jako wspaniały przyjaciel, znakomity nauczyciel, wybitny uczony, erudyta, człowiek wielu zainteresowań i pasji, otwarty dla wszystkich, dla którego zawsze priorytetem była praca naukowa. Najlepszym tego znakiem jest dzień pogrzebu, który jednocześnie był ostatnim dniem pracy etatowej w Instytucie Archeologii Uniwersytetu Łódzkiego.

Będzie Go bardzo brakowało polskiej archeologii i nam wszystkim. 